ISSN: 2276-7770 ICV: 6.15

Vol. 8(1), pp. 022-029, January, 2018

Copyright $\odot 2018$, the copyright of this article is retained by the author(s)

http://gjournals.org/GJAS



\title{
Soil Test Based Phosphorous Calibration for Fababean (Vicia faba L.) Production on Nitisols in Central Highlands of Ethiopian
}

\section{${ }^{\star}$ Girma Chala1, Gemechu Keneni², Zeleke Obsa ${ }^{2}$}

\author{
Holeta Agriculture Research Centre, EIAR , P.O. Box 31, Holeta, Ethiopia
}

\section{ARTICLE INFO}

Article No.: 011818007

DOI: 10.15580/GJAS.2018.1.011818007

Submitted: 18/01/2018

Accepted: $27 / 01 / 2018$

Published: 30/01/2018

${ }^{\star}$ Corresponding Author

Girma Chala

E-mail: chalagirma4@gmail.

Com

Keywords: Critical $P$

concentration, Fababean, Nitisol,

Phosphorous calibration, $P$

requirement factor, Relative yield
Soil test based phosphorous calibration study was conducted fababean on Nitisols of farmers' fields in West Shewa, in central highlands of Ethiopia. The experiment was arranged in a complete block design with six levels of phosphorous fertilizer $\left(0,5,10,15,20\right.$ and $\left.25 \mathrm{~kg} \mathrm{ha}^{-1}\right)$ with three replications. Results showed that grain yield of fababean were significantly affected by $\mathbf{P}$ fertilizer application rate. The application of phosphorous fertilizer at different rates increased grain yield, up to $58 \%$ more than the control. Extractable soil P concentrations (Bray II, 0- $20 \mathrm{~cm}$ depth) three weeks after planting significantly responded to $P$ fertilizer rate. Correlations of relative yield with Bray-2 soil test phosphorous values showed that the soil test phosphorous levels greater than $12.5 \mathrm{mg} \mathrm{kg}^{-1}$ (critical phosphorous concentration) was found to be sufficient for fababean production. The average phosphorous requirement factor (Pf) calculated from soil test phosphorous values of all treatments for the study area was 7.02. 


\section{INTRODUCTION}

Soil fertility is considered to be the major constraint in the highlands of Ethiopia due to continuous cultivation of these soils without adequate replenishment for long years. This made highland soils nutrient deficient particularly Nitrogen and Phosphorous. Nutrient depletion is rarely directly linked to food shortage, as it is a gradual process unlike natural disaster.

In Africa, several studies indicated that there is a widespread nutrient mining as compared to amendments both in quality and quantity resulting in a negative nutrient balance (Henao and Baanante, 1999). In Ethiopia, century-long, low-input agricultural production systems and poor agronomic management practices, limited awareness of communities and absence of proper land-use policies have aggravated soil fertility degradation. This has also encouraged the expansion of farming to marginal, non-cultivable lands, including steep landscapes and range lands.

Fababean is one of the most important grain legumes in Ethiopia in terms of area, production, source of protein and as a rotation crop ameliorating soil fertility. Despite the importance of the crop in the traditional farming systems, the yield is generally low due to several factors, among which poor soil fertility and inadequate plant nutrition, poor seedbed preparation, untimely sowing, sub-optimal weed control, and the lack of improved varieties are the major ones(Alem et al., 1990; Amahare and Adamu, 1994). The application of NP fertilizer significantly increased seed yields of fababean (Angaw and Asnake, 1994; Amahare et al., 1999). Phosphorus is, in fact, the most important growth limiting nutrient factor for pulses including fababean. Although blanket application of $18 / 20 \mathrm{~kg} \mathrm{NP} \mathrm{ha}^{-1}$ in the form of diammonium phosphate (DAP) has been recommended for fababean production in the country, this was not substantiated by research results (Amahare et al., 1999)

Phosphorous is the most yield limiting of soilsupplied elements, and soil $P$ tends to decline when soils are used for agriculture (David and David, 2012). Studies have demonstrated that Nitisol areas in the central highlands of Ethiopia are marginally to severely deficient in P (Taye et al., 1996). In Ethiopia, the blanket recommendations that are presently in use all over the country were issued several years ago, which may not be suitable for the current production systems (Taye et al., 2002, Gete et al., 2010). Since the spatial and temporal fertility variations in soils were not considered, farmers have been applying the same $\mathrm{P}$ fertilizer rate to their fields regardless of soil fertility differences.

Calibration is a means of establishing a relationship between a given soil test value and the yield response from adding nutrient to the soil as fertilizer. It provides information how much nutrient should be applied at a particular soil test value to optimize crop growth without excessive waste and confirm the validity of current $P$ recommendations (Evans 1987, McKenzeie and Kryzanowski 1997, 17-19). They enable to revise fertilizer recommendations for an area based on soil and crop type, $\mathrm{pH}$ and soil moisture content at time of planting. An accurate soil test interpretation requires knowledge of the relationship between the amount of a nutrient extracted by a given soil test and the amount of plant nutrients that should be added to achieve optimum yield for a particular crop (Muir and Hedge 2002, Watson and Mullen 2007). Soil tests are designed to help farmers predict the available nutrient status of their soils. Once the existing nutrient levels are established, producers can use the data to best manage what nutrients are applied, decide the application rate and make decisions concerning the profitability of their operations (Getachew and Berhane, 2013). However, local assessments for the soil $P$ critical levels and soil $P$ requirement factors even for the major crops of the country are negligible. Currently, soil fertility research improvement is agreed with respect to Site specific fertilizer recommendation in the country.

Soil test-based and specific nutrient management has been a major tool for increasing productivity of agricultural soils. The aim of the soil test calibration is to obtain correlation between the contents of the available nutrients in the soil and the crop responses to applications of nutrients in selected areas. Therefore, the objectives of this study were to correlate the Bray-2 soil test $P$ with the relative tuber yield response of fababean across selected Nitisol areas of West Shewa, to established preliminary agronomic interpretations, and to determine the critical $P$ concentration and $P$ requirement factor.

\section{MATERIALS AND METHODS}

\section{Experimental site}

Phosphorus response trials with fababean were conducted on farmers' fields in 2013, 2014 and 2015 during the main cropping seasons in West Shewa, in the central highlands of Ethiopia. Rainfall of $1100 \mathrm{~mm}$, about $85 \%$ of which falls from June to September and the rest from January to May and average minimum and maximum air temperatures of 6.2 and $22.1{ }^{\circ} \mathrm{C}$, respectively. The environment is seasonally humid and major soil type of the trial sites is Eutric Nitisol(FAO Soil Classification).

For the selection of representative trial sites across the area, over 320 soil samples $(0-20 \mathrm{~cm}$ depth) were collected in three years from farmers' fields before the onset of the trial. Soil samples were analyzed for $\mathrm{pH}$ using a ratio of $2.5 \mathrm{ml}$ water to $1 \mathrm{~g}$ soil available $\mathrm{P}$ using Bray-II method, Organic carbon was determined by the method of Nelson and Sommers (1982) and total nitrogen using Kjeldahl method (Jackson, 1958), exchangeable cations and cation exchange capacity (CEC) using ammonium acetate method at the soil and plant analysis laboratory of Holeta Agricultural Research Center. The available soil $P$ (using Bray-2 method) ranges prior to planting considered for classification 
were $<10 \mathrm{mg} \mathrm{P} \mathrm{kg}^{-1}$ for low, $10-25 \mathrm{mg} \mathrm{P} \mathrm{kg}^{-1}$ for medium, and $>25 \mathrm{mg} \mathrm{P} \mathrm{kg}^{-1}$ for high (Table 1). Based on this categorization, 4 farmers with low and medium fields available $P$ were selected for the first year, 5 farmers for the second year and 3 farmers with the same categories for the last two years, respectively.

\section{Experimental Procedures}

The experiment was arranged in randomized complete block design with six levels of phosphorus $(0,5,10,15$, 20 and $25 \mathrm{~kg} \mathrm{ha}^{-1}$ ) and replicated three times. The gross plot size was $4 \mathrm{~m} \times 5 \mathrm{~m}\left(20 \mathrm{~m}^{2}\right)$, and accommodating a minimum of 12 harvestable plants with different rows and space lengths. The net plot size was determined with area and plant density leaving the one outermost row and sides of each row the spacing between Plants, rows, plots and blocks were $0.10 \mathrm{~m}, 0.40 \mathrm{~m}, 0.5 \mathrm{~m}$ and $1 \mathrm{~m}$, respectively. The harvested plot area measured
$16 \mathrm{~m}^{2}$. The source of $P$ was triple super-phosphate (TSP). All agronomic practices were applied based on local research recommendations.

Land preparation was done at the end of May in accordance with a standard practice locally used. The experimental plot was cultivated by an oxen-drawn implement to the depth of $15-20 \mathrm{~cm}$. The land was levelled and ridges were made manually. An improved fababean cultivar (Moti) was planted to the specified treatments. Sowing was made from mid of June to the last week of June depending on the onset of rainfall. Cultivation, weeding, chemical spray and harvesting were done at the appropriate time according to the research recommendations.

Application of phosphorus fertilizer was done by banding the granules of TSP (Triple super-phosphate) at the depth of $10 \mathrm{~cm}$ below and around the seed at planting. Harvesting was done at physiological maturity when the leaves of the fababean plants senesced.

Table1: Soil nutrient contents of the trial sites before planting fababean in 2013-2015

\begin{tabular}{|l|l|l|l|l|l|l|}
\hline $\begin{array}{l}\text { Site/farmers' } \\
\text { name }\end{array}$ & $\begin{array}{l}\mathrm{pH}(1: 2.5 \\
\left.\mathrm{H}_{2} \mathrm{O}\right)\end{array}$ & Total N (\%) & $\mathrm{P}^{*}\left(\mathrm{mg} \mathrm{kg}^{-1}\right)$ & $\begin{array}{l}\mathrm{K}\left(\mathrm{meq}^{-1}\right. \\
\left.1000 \mathrm{~g}^{-1}\right)\end{array}$ & $\begin{array}{l}\mathrm{Na}\left(\mathrm{cmol}_{\mathrm{c}} \mathrm{kg}^{-}\right. \\
1)\end{array}$ & $\mathrm{CEC}$ \\
\hline Bizuayehu & 4.2 & 0.18 & 7.6 & 0.64 & 0.14 & 18.4 \\
\hline Beyene & 4.6 & 0.16 & 6.8 & 0.68 & 0.16 & 21.6 \\
\hline Aselefechi & 4.4 & 0.18 & 6.2 & 0.72 & 0.18 & 16.1 \\
\hline Gemechu & 4.2 & 0.15 & 7.8 & 0.54 & 0.14 & 15.4 \\
\hline Legesse & 5.2 & 0.21 & 7.8 & 0.58 & 0.17 & 16.8 \\
\hline Bekele & 4.6 & 0.17 & 7.2 & 0.62 & 0.18 & 20.4 \\
\hline Ayenelem & 4.2 & 0.18 & 8.2 & 0.68 & 0.15 & 20.2 \\
\hline Teshome & 4.4 & 0.18 & 6.6 & 0.64 & 0.16 & 22.8 \\
\hline Nuru & 4.6 & 0.16 & 7.6 & 0.62 & 0.14 & 18.6 \\
\hline Irko & 4.4 & 0.17 & 7.4 & 0.76 & 0.15 & 21.2 \\
\hline Gudisa & 4.6 & 0.18 & 6.8 & 0.78 & 0.16 & 18.4 \\
\hline Hunde & 4.8 & 0.14 & 6.6 & 0.72 & 0.15 & 22.2 \\
\hline
\end{tabular}

*Bray-2 method

Agronomic parameters collected were Stand count at complete emergence, plant height $(\mathrm{cm})$, was measured by taking five randomly reselected plants per plot as the distance in $\mathrm{cm}$ from the soil surface to the top most growth point of aboveground at full maturity. Days to maturate from emergence to maturity was recorded when $95 \%$ percent of the plants of different treatments were ready for harvest, pods per plant and seeds per pod (average of five plants), total above ground biomass and seed yields and thousand seed weight. The harvested materials were sun-dried and manually threshed. After threshing, seeds were cleaned, weighed and adjusted at the 10\% moisture level. The total biomass and seed yields recorded on plot basis were converted to $\mathrm{kg} \mathrm{ha}^{-1}$ for statistical analysis.

Determination of critical $P$ concentration (Pc): to correlate relative yield vs soil test $P$ values and determine critical $\mathrm{P}$ concentration, the available $\mathrm{P}$ was extracted from the soil samples taken three weeks after planting from each plot of all experimental fields using Bray-2 method.

The Cate-Nelson graphical method (Dahnke and Olsen, 1990) was determine the critical $P$ value using relative yields and soil test $P$ values obtained from $12 \mathrm{P}$ fertilizer trials conducted at different sites. To assess the relationship between tuber yield response to nutrient rates and soil test $P$ values, relative grain yields in percent were calculated as follows:

$$
\text { Relative yield(\%): } \frac{\text { yield }}{\text { maximum yield }} \times 100
$$

The scatter diagram of relative of relative yield ( $y$-axis) versus soil test values ( $X$-axis) was plotted. The range in values on the $\mathrm{Y}$-axis was 0 to $100 \%$. A pair of intersecting perpendicular lines was drawn to divide the data into four quadrants. The vertical line defines the responsive and non-responsive ranges. The observations in the upper left quadrants overestimate the $P$ fertilizer $P$ requirement while the observations in 
the lower right quadrant underestimate the fertilizer requirement. The intersecting lines were moved about horizontally and vertically on the graph, always with the two lines parallel to the two axes on the graph, until the number of points in the two positive quadrants was at a maximum (or conversely, the number of points in the two negative quadrants was at a minimum). The point where the vertical line crosses the $\mathrm{X}$-axis was defined as optimum critical soil test level (Dahnke and Olsen, 1990).

Determination of $P$ requirement factor $\left(P_{f}\right)$ : phosphorus requirement factor $\left(p_{f}\right)$ is the amount of $P$ in $\mathrm{kg}$ needed to raise the soil $P$ by $1 \mathrm{mg} \mathrm{kg}^{-1}$. It enables to determine the quantity of $\mathrm{P}$ required per hectare to raise the soil test by $1 \mathrm{mg} \mathrm{kg}^{-1}$, and to determine the amount of fertilizer required per hectare to bring the level of available $\mathrm{P}$ above the critical level (Nelson and Anderson, 1977, 19-39). It was calculated using available $P$ values in samples collected from unfertilized and fertilized plots. Phosphorous requirement factor was expressed as:

$$
\text { Pf }=\frac{k g \text { P applied }}{\Delta \text { Soil } P}
$$

Therefore the rate of $\mathrm{P}$ fertilizer to be applied $(\mathrm{Pa})$ was expressed in terms of critical $\mathrm{P}$ concentration $\left(P_{c}\right)$, initial soil $\mathrm{P}$ value $\left(P_{i}\right)$ and $\mathrm{P}$ requirement factor $\left(P_{f}\right)$.

$$
P a=(P c-P i) x P f
$$

\section{Statistical analysis}

The data were subjected to analysis of variance using the procedure of the SAS statistical package version 9.0 (SAS Institute, 2001). The total variability for each trait was quantified using the following model.

$$
T i j k=\mu+Y i+R j(i)+P k+P Y(i k)+e i j k
$$

Where $T_{i j k}$ is the total observation, $\mu=$ grand mean, $Y_{i}=$ effect of the $i^{\text {th }}$ year, $R_{j(i)}$ is the effect of the $j^{\text {th }}$ replication(with in the $i^{\text {th }}$ year), $P_{k}$ is the effect of the $k^{\text {th }}$ treatment, $P Y_{(i k)}$ is the interaction of $k^{\text {th }}$ treatment with $\mathrm{i}^{\text {th }}$ year and $e_{i j k}$ is the random error. Means for the main effects were compared using the means statement with the least significant difference (LSD) test at the 5\% level.

\section{RESULTS}

\section{Weather}

The total rainfall amount and precipitation pattern for 2013 was significantly higher compared with long-term average, 2014 and 2015(Figure 1).The rainfall amounts recorded for August and Jul were considerably higher in 2013 than 2014 and 2015. This means average moisture received in 2013 was conducive for fababean growth. Deficiency of moisture in September and October critically limited the numbers of pod and grain filling of fababean production.

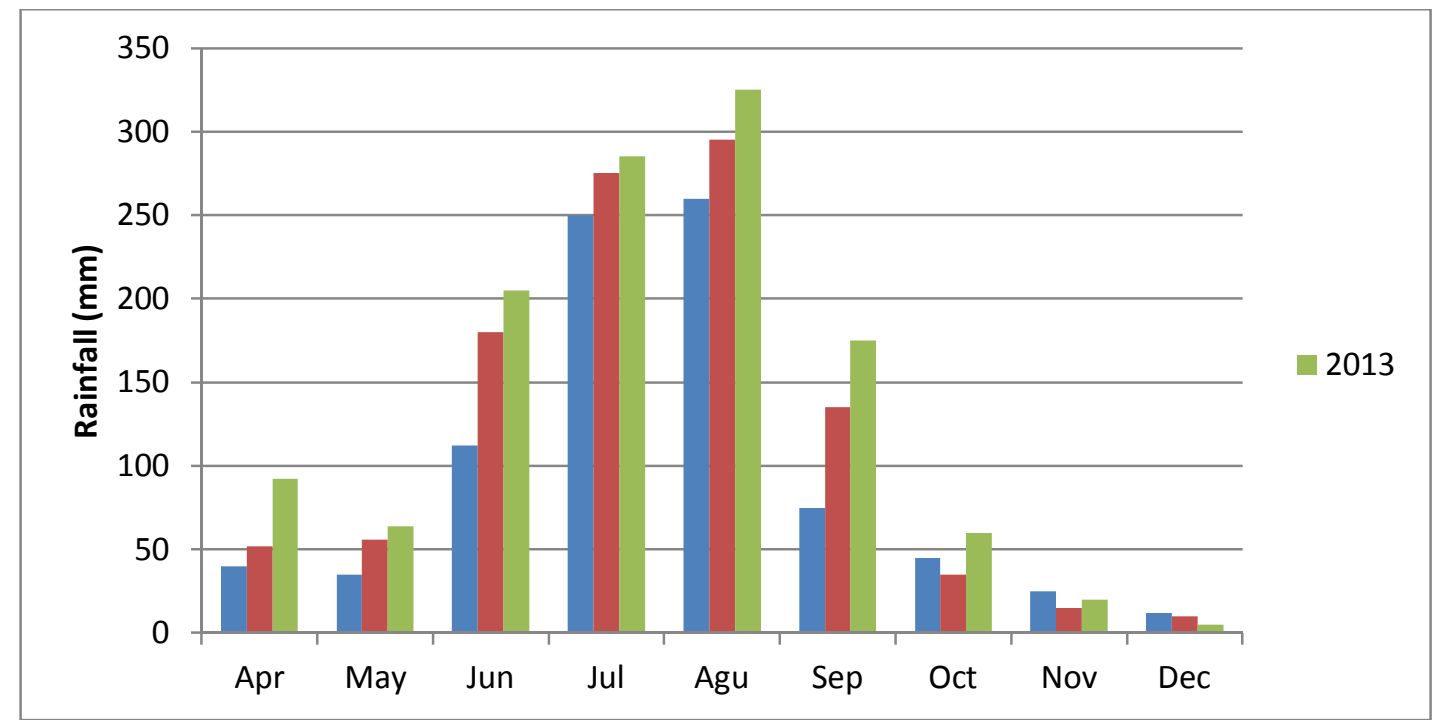

Figure 1: Monthly total rainfall for 30 year average, 2013, 2014 and 2015 cropping season's rain fall at Holeta and around the trial sites. 


\section{Yield and yield components}

The responses of plant height, thousand seed weight, grain and biomass yield of fababean to phosphorus fertilization, year and interaction of year by phosphorus of the combined data of over three years are demonstrated in (Table 2). Analysis of variance over three year cropping seasons showed that the year effect was significant ( $p \leq 0.05$ and 0.01$)$ for yield and yield components of fababean (Table 2). The highest mean of grain yield $\left(2180.5 \mathrm{~kg} \mathrm{ha}^{-1}\right)$ was obtained in the year 2015 relatively compared to the yield $\left(1966.2 \mathrm{~kg} \mathrm{ha}^{-1}\right.$ and $2133.9 \mathrm{~kg} \mathrm{ha}^{-1}$ ) achieved in 2013 and 2014 respectively (Table 3 ).

Table 2: Effects of year, $P$ fertilizer rate and their interaction on yield components of fababean across sites in 2013, 2014 and 2015

\begin{tabular}{|l|l|l|l|}
\hline Parameters & Year $(\mathrm{Y})$ & Phosphorous $(\mathrm{P})$ & $\mathrm{Y}{ }^{*} \mathrm{P}$ \\
\hline Plant height & ${ }^{*}$ & ${ }^{*}$ & Ns \\
\hline Grain yield & ${ }^{*}$ & ${ }^{* *}$ & Ns \\
\hline Biomass yield & ${ }^{* *}$ & Ns \\
\hline Thousand seed weight & ${ }^{*}$ & ${ }^{*}$ & Ns \\
\hline
\end{tabular}

${ }^{*},{ }^{* *}$ Significant at 0.05 and 0.01 probability levels, respectively; ns, not significant

The maximum plant height, grain yield, biomass yield and thousand seed weight were recorded in 2015 cropping season (Table 3). The effects of year by $P$ fertilizer rate $(Y \times P)$ were not significant $(P \leq 0.05)$ for grain yield and yield components (Table 3 ). Significantly higher grain yields were obtained from the application of
$20 \mathrm{~kg} \mathrm{P}$ ha- $^{-1}$. The application of $\mathrm{P}$ fertilizer at rates of 5 , $10,15,25$ and $20 \mathrm{~kg} \mathrm{ha}^{-1}$ increased grain yield of fababean by $25,28,42$ and $58 \%$, respectively, compared to the control(without P fertilizer). Grain yield consistently increased as $\mathrm{P}$ rate increased, but showed slight decrease beyond $20 \mathrm{~kg}^{-1}$.

Table 3: Table of means for main effects of $P$ application year and fertilizer rate on fababean parameters in 2013, 2014 and 2015

\begin{tabular}{lllll}
\hline Factor & Plant height $(\mathrm{cm})$ & Grain yield $(\mathrm{kg})$ & $\begin{array}{l}\text { Biomass } \\
\text { (ton/ha) }\end{array}$ & $\begin{array}{c}\text { yield } \\
\text { Thousand } \\
\text { weight }(\mathrm{gm})\end{array}$ \\
\hline Year & & & \\
2013 & $131.6^{\mathrm{c}}$ & $2133.9^{\mathrm{a}}$ & $45.24^{\mathrm{a}}$ & $754.2^{\mathrm{a}}$ \\
2014 & $133.7^{\mathrm{b}}$ & $1966.2^{\mathrm{b}}$ & $41.47^{\mathrm{b}}$ & $755.18^{\mathrm{b}}$ \\
2015 & $136.3^{\mathrm{a}}$ & $2180.5^{\mathrm{a}}$ & $45.6^{\mathrm{a}}$ & $765.9^{\mathrm{a}}$ \\
\hline Phosphorous & & & \\
\hline 0 & $129.4^{\mathrm{b}}$ & $1630.1^{\mathrm{d}}$ & $37.29^{\mathrm{c}}$ & $686.7^{\mathrm{c}}$ \\
5 & $132.7^{\mathrm{b}}$ & $1958.1^{\mathrm{c}}$ & $42.7^{\mathrm{b}}$ & $755.2^{\mathrm{ab}}$ \\
10 & $128.9^{\mathrm{b}}$ & $2042.2^{\mathrm{c}}$ & $41.96^{\mathrm{bc}}$ & $765.9^{\mathrm{ab}}$ \\
15 & $129.7^{\mathrm{b}}$ & $2077.8^{\mathrm{c}}$ & $45.2^{\mathrm{b}}$ & $790.9^{\mathrm{a}}$ \\
20 & $136.7^{\mathrm{ab}}$ & $2580.2^{\mathrm{a}}$ & $52.9^{\mathrm{a}}$ & $781.7^{\mathrm{ab}}$ \\
25 & $143.9^{\mathrm{a}}$ & $2307.7^{\mathrm{b}}$ & $45.2^{\mathrm{b}}$ & $725.4^{\mathrm{bc}}$ \\
\hline CV & 11.34 & 17.4 & 19.3 & 13.6 \\
\hline
\end{tabular}

Within each column, means with different letters are significantly different at $P<0.05$; CV, coefficient of variation

\section{Critical $P$ concentration $(P c)$ and $P$ requirement factor (Pf)}

Soil $P$ values determined three weeks after planting differed significantly $(P \leq 0.01)$ among $P$ levels. The main effect of $P$ fertilizer treatments resulted in mean soil test $P$ values 4.6 to $12.5 \mathrm{mg} \mathrm{kg}^{-1}$ (Table 4 ). Bray-2 soil test $P$ values below $10 \mathrm{mg} \mathrm{kg}^{-1}$ are considered low. The increase in soil $P$ content in response to $P$ fertilizer application was linear up to $20 \mathrm{~kg} \mathrm{P} \mathrm{ha}^{-1}$. The highest mean soil $\mathrm{P}$ concentration (12.2 $\mathrm{mg} \mathrm{kg}^{-1}$ ) was recorded from $20 \mathrm{~kg} \mathrm{P} \mathrm{ha}^{-1}$ (Table 4). 


\section{Phosphorous critical concentration}



Figure 2: Relationships between relative yield response of fababean and soil-test $\mathbf{P}$ measured using Bray-2 method. The arrow indicates the critical $P$ concentration $(P c)$ for fababean on Nitisols.

Table 4: Determination of $P$ requirement factor for fababean on Nitisols in 2013, 2014 and 2015

\begin{tabular}{|c|c|c|c|c|c|}
\hline \multirow{2}{*}{$\begin{array}{l}\text { Phosphorous } \\
\text { rate }(\mathrm{kg} / \mathrm{ha})\end{array}$} & \multicolumn{2}{|c|}{ Soil test $\mathrm{P}($ Bray- II) } & \multirow{2}{*}{$\begin{array}{l}\mathrm{P} \text { increase } \\
\text { Control }\end{array}$} & \multirow[t]{2}{*}{ over } & \multirow{2}{*}{$\begin{array}{l}\mathrm{P} \text { requirement } \\
\text { factor }(\mathrm{Pf})\end{array}$} \\
\hline & Range & Average & & & \\
\hline 0 & $6.2-18.2$ & 8.8 & & & \\
\hline 5 & $6.4-21.0$ & 9.9 & 1.1 & & 4.6 \\
\hline 10 & $7.2-23.1$ & 10.4 & 1.6 & & 6.3 \\
\hline 15 & $7.4-22.8$ & 11.4 & 2.6 & & 5.8 \\
\hline 20 & $7.6-26.3$ & 12.2 & 3.4 & & 5.9 \\
\hline 25 & $6.8-22.4$ & 10.8 & 2.0 & & 12.5 \\
\hline Average & & & & & 7.02 \\
\hline
\end{tabular}

The relationship between relative fababean yield response and soil $P$ measured with the Bray-2 method is shown in the figure 2 . The critical $P$ concentration $(P C)$ was determined from the scatter diagram drawn using relative tuber yields of fababean and the corresponding soil test $P$ values for all $P$ levels $\left(0-25 \mathrm{~kg} \mathrm{ha}^{-1}\right)$. The $P C$ defined by the Cate- Nelson method in this study was about $12.5 \mathrm{mg} \mathrm{P} \mathrm{Kg}^{-1}$, with mean relative grain yield response of about $80 \%$ (Figure 2).

When the soil test value is below the critical level addition all information is needed on the quantity of $P$ required elevating the soil $P$ to the required level. This is the $P$ requirement factor $(P f)$, the amount of $P$ required to raise the soil test $P$ by $1 \mathrm{mg} \mathrm{kg}^{-1}$, computed from the from the difference between available soil test $P$ values from plots that received $0-25 \mathrm{~kg} \mathrm{P}$ ha $^{-1}$ using the second formula motioned above. Accordingly the calculated $P f$ were 4.6-12.5 and the overall average $P f$ of all treatments for the study area were 7.02(Table 4). Thus the rate of $P$ fertilizer required per ha can be calculated using the soil critical $P$ concentration, initial soil $\mathrm{P}$ determined for each site before planting (Table 1) and the $P$ requirement factor as indicated above in the third formula.

\section{DISCUSSION}

Our results showed that significant variations in yield and other agronomic parameters were observed due to cropping season. In rain-fed environments, the maximum yield attainable at any given location depends not only on the soil available nutrients and the amounts of fertilizer applied but also on the amount and distribution of rainfall during the crop season, and incidence of diseases, insect pests, weed infestation and although yield- limiting factors are complex. Availability of nutrients to crops is a function of the soil, crop, environment, and management; their interactions affects fertilizer use efficiency and the crop growth condition (Smilde 1987; Fageria 2009, Agegnehu et al., 2013). These factors need to be considered when using 
methods to calibrate soil- test nutrient values with relative grain yields. Something that should be considered in this region in future is the interaction of $\mathrm{P}$ response with $\mathrm{N}$ supply, soil $\mathrm{pH}$, and with weather condition.

According to Jones (2011) low nutrient uptake of uptake early in a plant's growth lowers nutrient quantity for the seed affecting yield. Analysis of variance show that phosphorous had a highly significant effect on yield and yield component of fababean. Grain yield consistently increased as the rate of $P$ increased up to $20 \mathrm{~kg} \mathrm{P} \mathrm{ha}^{-1}$ then a slight decrease in yield was observed at the highest $P$ rate $\left(25 \mathrm{~kg} \mathrm{P} \mathrm{ha}^{-1}\right)$ (Table3).

According to the Cate- Nelson method, the critical levels of Bray-2 P in the top $15 \mathrm{~cm}$ of soil about $12.5 \mathrm{mg} \mathrm{kg}^{-1}$; at values of greater than or equal to 12.5 $\mathrm{mg} \mathrm{kg}^{-1}$, the crop achieved about $80 \%$ of its maximal yield in the absence of $P$ fertilizer application (figure 3 ). This implies that $P$ fertilizer application could be recommended for a build-up of the soil $P$ to this critical value, or maintaining the soil $P$ at this level. Increasing $P$ beyond this level, the cost of additional $P$ fertilizer to produce extra yield would likely be greater than the value of additional yield. Thus, in soils with available $P$ status below $12.5 \mathrm{mg} \mathrm{kg}^{-1}$, yield of potato could show a significant response to applications of $\mathrm{P}$ fertilizers. Whereas in areas with available $P$ status greater than $12.5 \mathrm{mg} \mathrm{kg}^{-1}$, the $\mathrm{P}$ concentration in the soil exceeds crop needs so that further addition of $P$ fertilizer may not result in a profitable yield increase.

According to the result of our study, some yield response sites to $\mathrm{P}$ fertilizer applications had soil test levels above the critical level. Hence, to protect a potential loss of fababean yield, at least a maintenance application of $12.5 \mathrm{~kg} \mathrm{P}^{-1}$ may be required depending on the grain yield goal and profitability. Phosphorous fertilizer application at optimum level is necessary to improve grain yield of fababean. Soil fertility is suboptimal for the production of fababean in Ethiopian highlands, particularly on Nitisols where soil $\mathrm{pH}$ and the associated $\mathrm{P}$ availability is low. Following the preplanting soil analysis results all of the trial sites had lower soil $P$ values than the critical $P$ concentration. This had a direct relationship with the crop growth and grain yields. In most cases, soil pH less than 5.5 is deficient in available $\mathrm{P}$ and exchangeable cations (Brady and Weil, 2010). In such soils the proportion of $P$ fertilizer that could be available to a crop becomes inadequate (Brady and Weil, 2010), unless amended through organic matter maintenance or liming.

The results seem promising and could be used as a basis for soil-test $\mathrm{P}$ fertilizer recommendation for the production of fababean on Nitisol areas of central Ethiopian highlands and to develop an effective guideline for wider applicability of soil test based fertilizer recommendations, more research assisted by appropriate soil $\mathrm{P}$ extraction methods is required to generate sufficient information for the most important crop-soil systems.

\section{CONCLUSION}

There were clear positive effects of $P$ fertilizer on yield and yield components of fababean on Nitisols of central highlands of Ethiopia. Across all 12 sites, the critical soil $P$ concentration was $12.5 \mathrm{mg} \mathrm{ka}^{-1}$ (Bray 2 method). The results may be used as a basis for $P$ fertilizer recommendations for the production of fababean on Nitisol areas of Ethiopian highlands. They can also be used for future intensification in other areas for developing a system for soil- test $P$ fertilizer recommendations. Further field trials involving different $\mathrm{N}$ levels, climatic conditions, soil $\mathrm{P}$ test methods, and perhaps limiting treatments, would further our understanding of limiting factors and facilitate better fertilizer recommendations.

\section{ACKNOWLEDGEMENTS}

The authors acknowledge the Ethiopian Institute of Agricultural Research (EIAR) and I would like to express my appreciation also to Mr. Haile Beza, Mr. Beyene Ofa, Mr. Tesfaye Negash, Mrs. Kessach Birhanu, and Mrs. Tsige Kebede for their technical assistance during the execution of the experiments under field condition. Appreciation is also due for the services of the analytical soil laboratory of Holeta Agricultural Research Center of EIAR.

\section{REFERENCES}

1. Alem Berhe, S.P.S. Beniwal, Amare Ghizaw, Asfaw Telaye, Hailu Beyene, and M.C. Saxena. 1990. On - farm evaluation of four management factors for fababean production in the Holeta Zone of West Shewa. Ethiopian J. Agricultural Science 12: 17-28.

2. Amare Ghizaw and Adamu Molla. 1994. Faba bean and field pea agronomy research. P.199-229. In Asfaw Telaye (eds) cool-season food legumes of Ethiopia. Proc. First National cool-season food legumes review conference,16-20 December 1993, Addis Ababa Ethiopia. ICARDA/IAR: ICARDA, Aleppo,Sryia.

3. Amare Ghizaw, Tekelign Mamo, Adamu Molla, Zewdu Yilma, and Yeshanew Ashagre. 1999. Nitrogen and phosphorous effects on faba bean yield and yield components. J. Agronomy and crop Science 182: 167-174.

4. Angaw Tsigye, and Asnakew Woldeab. 1994. Fertilizer response trials on highland food legumes. P. 279-292. In Asfaw Telaye (eds) cool-season food legumes of Ethiopia. Proc. First National coolseason food legumes review conference,16-20 December 1993, Addis Ababa Ethiopia. ICARDA/IAR: ICARDA, Aleppo, Sryia. 
5. Brady, NC.and R.R. Weil.2010. Elements of the nature and properties of soils. Pearson education International. New Jersey.

6. Dahnke, W.C. and R.A. Olsen.1990. Soil test correlation, calibration , and recommendation. P 4571. In: R.L. Westerman(ed.) soil testing and plant analysis, $3^{\text {rd }}$ ed., SSSA Book Series: 3, Soil science society of America, Madison, WI.

7. David,M. E, and J.T. David. 2012. Modeling an Improvement in phosphorous utilization in Tropical Agriculture. Journal of Sustainable Agriculture, 36: 18-35.

8. Evans, C.E. 1987. "Soil test calibration. Soil testing, sampling, correlation, calibration, and interpretation." Soil Science Society of America, SSSA special publication no. 21, USA.

9. Fageria,N.K. 2009. The use of nutrients in crop plants. New York: CRC Press.

10. Getachew Agegnehu and Berhane Lakew. 2013. Soil test phosphorous calibration for malt barley production on Nitisols of Ethiopian highlands. Trop.Agric. 90: 177 -187.

11. Gete Zeleke, Getachew Agegnehu, Dejene Abera, and Sofia Rashid 2010. Fertilizer and soil fertility potential in Ethiopia: Constraints and opportunities for enhancing the system. Washington, DC: IFPRI.

12. Henao, J. and Baanante, C.A. (1999). "Nutrient Depletion in the Agricultural Soils of Africa".

13. International Food Policy Research Institute. Vision 2020 Brief No. 62.

14. Jackson, M.L., 1958. Soil chemical analysis. Prentice Hall, Inc., Englewood Cliffs. Newjers.

15. Jones, C., Olson-Rutz, K., C.P, Dinkins. 2011. Nutrirent uptake Timing by Crops: to assist with fertilizing decisions. Montana State University. USA.

16. McKenizie, R.H., and L. Kryzanowski. 1997. "Soil testing methods calibrated to phosphate fertilizer trials." Better Crops 81: 17-19.
17. Muir, J.H. and J.A. Hedge. 2002. "Corn response to phosphorous and potassium fertilization at different soil test levels." In Arkansas Soil Fertility Stugies edited by N.A.Slaton, 490: 32-33. University of Arkansas Agricultural Experiment Station Research Series.

18. Nelson, L.A., and R.L. Anderson. 1997. Partitioning soil test-crop response probability. In Soil testing: Correlating and interpreting the analytical results, ed T.R.Peck, 19-39. Madison, WI: American Society of Agronomy.

19. Nelson, N.A, and Sommer, 1982. Photometric adaptation of Somogy method for the determination of glucose. Journal of Biological Chemistry, 153: 375-380. Nonnecke, I.L., 1989. Vegetable Production, New York. 657p.

20. Smilde, K. W. 1987. Establishment of fertilizer recommendations on the basis of soil tests. In Soil test calibration in West Asia and North Africa, eds A. Matar, P.N. Soltanpour, and A. Chouinard, 1-11. Ankara, Turkey.

21. Taye Bekele, Balesh Tulema and Gebrageorges Gebre Kidan. 1996. "Soil fertility management in Barley." In Barley research in Ethiopia: past work and future prospects edited by Hailu Gebre, van J. Leur, 92-99. IAR/ICARDA, Addis Ababa, Ethiopia.

22. Taye Bekele, Dereje Gorfu and Selamiuhun Sertsu 2002. Results of Phosphorous Soil Test Calibration Study in Hetosa Werede, Arsi zone: Proceeding of the Workshop on phosphorous soil test calibration Study. Addis Ababa, Ethiopia: EIAR.

23. Watson, M. and R. Mullen. 2007. "Understanding soil test for plant- available phosphorous." Ohio State University, USA. 